\title{
TAKEN BY STORM: BUSINESS SURVIVAL IN THE AFTERMATH OF HURRICANE
} KATRINA*

\author{
by
}

\author{
Emek Basker \\ University of Missouri
}

\author{
Javier Miranda \\ US Census Bureau
}

\section{CES 14-20 April, 2014}

The research program of the Center for Economic Studies (CES) produces a wide range of economic analyses to improve the statistical programs of the U.S. Census Bureau. Many of these analyses take the form of CES research papers. The papers have not undergone the review accorded Census Bureau publications and no endorsement should be inferred. Any opinions and conclusions expressed herein are those of the author(s) and do not necessarily represent the views of the U.S. Census Bureau. All results have been reviewed to ensure that no confidential information is disclosed. Republication in whole or part must be cleared with the authors.

To obtain information about the series, see www.census.gov/ces or contact Fariha Kamal, Editor, Discussion Papers, U.S. Census Bureau, Center for Economic Studies 2K132B, 4600 Silver Hill Road, Washington, DC 20233, CES.Papers.List@census.gov. 


\begin{abstract}
We use Hurricane Katrina's damage to the Mississippi coast in 2005 as a natural experiment to study business survival in the aftermath of a cost shock. We find that damaged establishments that returned to operation were more resilient than those that had never been damaged. This effect is particularly strong for establishments belonging to younger and smaller firms. The effect of damage on establishments in older and larger chains was more limited, and they were subsequently less resilient having survived the damage. These selection effects persist up to five years after the initial shock. We interpret these findings as evidence that the effect of the shock is tied to the presence of financial and other constraints.
\end{abstract}

Keyword: Retail, chain, credit constraints, hurricane, Katrina, natural disaster, exit

JEL Classification: D22, L11, L81, L83, Q54

*Comments welcome. Author contact: emek@missouri.edu, javier.miranda@census.gov. Any opinions and conclusions expressed herein are those of the authors and do not necessarily represent the views of the U.S. Census Bureau. All results have been reviewed to ensure that no confidential information is disclosed. We thank Saku Aura, Randy Becker, David Brown, Jeff Brown, Jeff Czajkowski, Steve Fazzari, Teresa Fort, Lucia Foster, Jeff Groen, Hanna Halaburda, Ron Jarmin, Shawn Klimek, Traci Mach, Erika McEntarfer, Justin Pierce, Allison Plyer, Anne Polivka, Melissa Schigoda, Chad Syverson, and seminar participants at the U.S. Census Bureau, Iowa State University, Tel-Aviv University, Dartmouth College, Boston College, Harvard Business School, the 2011 Southern Economic Association meetings (Washington DC), the 2012 NBER Universities Research Conference, the 2012 FTC Microeconomics Conference, the 2013 NBER/CRIW Summer Institute, and the 2014 AEA for helpful comments and conversations. This research was started while Basker was an ASA/NSF/Census Bureau Fellow visiting the Center for Economic Studies (CES) at the U.S. Census Bureau. Basker thanks the funding agencies for their generous support and the economists at CES for their hospitality.. 


\section{Introduction}

Hurricane Katrina's landfall in the fall of 2005 famously breached levees, flooding New Orleans. It also unleashed wind gusts and a storm surge that destroyed hundreds of buildings along the Mississippi Gulf Coast. In this paper, we study the effect of direct storm-inflicted damage on business exits, focusing on the Mississippi coast. We use data from the Census Bureau's Longitudinal Business Database (LBD) on approximately 10,000 business establishments in Mississippi, including nearly 2,300 businesses in four counties with significant storm damage, combined with precise information on the location and extent of storm damage from the Federal Emergency Management Administration (FEMA). These data allow us to pinpoint which establishments were damaged or destroyed by wind or storm surge and which were left intact in the same area. We focus on establishments in the retail, restaurant, and hotel sectors, whose locations are non-fungible. Our identification comes from the randomness of actual damage within a fairly limited geographic area.

We find that the storm generated significant "excess exits" of physically damaged establishments in the short run, creating a 20-25 point wedge between the survival rate of damaged and undamaged businesses in Mississippi. This suggests that short-term distress may have caused businesses that would otherwise have survived to cease operation. In the long run, we find that businesses that weathered storm damage and returned to operation were more resilient (less likely to exit) than those left undamaged. We interpret this result as a "cleansing" or selection effect of the storm.

Reminiscent of the cleansing models in Caballero and Hammour (1994, 1996), we find the selection we observe may not be efficient. Although exiting establishments were, on average, less productive than continuers, even controlling for productivity we find that the brunt of the effect of storm damage on short-run survival fell on younger and smaller firms. Establishments in older and larger firms were more likely to rebuild and resume operations. Ceteris paribus, a doubling of the size of the chain to which an establishment belongs is associated with a 1.5 point reduction in the impact of extensive or catastrophic storm damage 
on the probability of exit between 2004 and 2006, and a doubling of the age of the firm to which an establishment belongs is associated with a 4.5 point reduction in the impact of extensive or catastrophic damage on the probability of exit between 2004 and 2006. Older and larger firms have lower exit rates even in undamaged areas, but having been hit by storm damage approximately doubles the advantage that these firms have over their smaller and younger counterparts. ${ }^{1}$ These findings are not driven by differences in productivity between older and younger, and larger and smaller, firms.

In the years after 2006, we find that age and size remain positively correlated with survival for undamaged establishments, but these relationships are considerably muted or even reversed among survivors of storm damage. For example, between 2006 and 2008, a doubling of the age of a firm to which an establishment belongs is associated with a 2.2point decrease in exit probability among establishments that were not damaged in the storm, but with a 6-point increase in exit probability among establishments that overcame storm damage.

We also find that among sole proprietors - a subset of the population which is dominated by small businesses - female-owned businesses experienced dramatically higher initial exit rates than their male-owned counterparts following physical damage but were somewhat more resilient than male-owned businesses in the long run. This finding corroborates the main finding and alleviates concerns that the estimated size and age effects are driven by any remaining unobserved post-Katrina demand shocks. These results also suggest the importance of considering owner demographic when examining the heterogeneity in firm response to shocks.

\footnotetext{
${ }^{1}$ The observation that exit rates are highest among small and young firms is not new; see, e.g., Dunne, Roberts, and Samuelson (1988); Davis, Haltiwanger, and Schuh (1996). More recently, evidence of higher exit rates for young/small business can be found in Haltiwanger, Jarmin, and Miranda (2013) and Fort, Haltiwanger, Jarmin, and Miranda (2013). Our contribution is to show how these characteristics interact with a shock to costs, using a control group of relatively unaffected businesses.
} 
We interpret our results as a complementary selection effect on two dimensions: profitability and access to credit. The more constrained a firm's access to credit, the higher the profitability threshold it must pass to receive this credit. As a result, establishments that survive storm damage and return to operation are both more profitable than those that exit and better able to access capital and other resources required to rebuild. Large and old firms experience less selection based on expected future performance because they have access to relatively cheap capital. In contrast, smaller and younger firms face much more binding credit and resource constraints so only the most profitable and productive can avoid early exit in the aftermath of the cost shock represented by storm damage. Among small and young firms, these twin selection mechanisms result in the survival of only "superstar" establishments, whereas larger and more established firms can afford to return a broader range of establishments to operation. This interpretation is consistent with long-established evidence that shows that young and small firms are relatively financially constrained (see, e.g., Mishkin, 2008; Calomiris and Hubbard, 1990; Fazzari, Hubbard, and Petersen, 1988). It is also consistent with evidence that policy interventions providing credit and knowhow have a disproportionate effect on small firms (see, e.g., Jarmin, 1999; Brown and Earle, 2013). Our results provide further evidence on the asymmetric response to shocks and new evidence about selection effects and follow-on dynamics.

Our paper is related to a broad literature exploring the impact of exogenous shocks on real economic activity, and to a small but growing literature on the effects of natural disasters on businesses and labor markets.

A number of papers assess how exogenous macroeconomic shocks, including monetary shocks, demand shocks, energy shocks, and technology shocks, affect the real economy. Within this literature, the papers most closely related to ours examine the differential effect of these shocks on firms of different size and age. For example, Gertler and Gilchrest (1994) and Sharpe (1994) find that small firms are more sensitive to monetary and business cycle shocks, and Fort, Haltiwanger, Jarmin, and Miranda (2013), using similar data to ours, find 
young and small firms are more sensitive to housing price shocks underscoring the potential importance of less traditional forms of financing for these firms.

A common difficulty faced by studies of macroeconomic shocks is disentangling cost shocks associated with business cycles, for example as a result of an increase in the cost of financing due to an increase in interest rates or the collapse of collateral values, from demand shocks associated with the same cycles. Mississippi's post-Katrina experience allows us to plausibly circumvent this problem because damage was extremely localized, infrastructure was largely unaffected (and where infrastructure was damaged, repair times were fairly short), and there was no significant population outflow from the affected areas. ${ }^{2}$

Most of the disaster literature focuses on assessing the impact of natural shocks on employment and growth outcomes. Along these lines, Strobl (2011) uses county-level data to estimate the effects of hurricanes on net growth, Belasen and Polachek (2009) estimate county-level effects of hurricanes on employment and earnings, and Ewing and Kruse (2005) estimate the short- and long-term effects of hurricanes on unemployment and economic activity. In contrast, our paper uses establishment-level data to isolate the direct effect of physical storm-related damage on the establishment's survival. Closer to the spirit of our paper, Leiter, Oberhofer, and Raschky (2009) use establishment-level data on European firms to test for "creative destruction" in the aftermath of flooding. A key difference between our paper and theirs is that they have damage data only at a more aggregate level (roughly equivalent to a county), whereas we have geocoded establishment-level data on damage. This allows us to analyze heterogeneous effects of storm damage and to establish the importance of firm age and size to the impact of damage. Siodla (2013) studies the effect of another disaster, the 1906 San Francisco fire, on businesses, but focuses on relocation rather than survival.

\footnotetext{
${ }^{2}$ This contrast dramatically with the situation in Louisiana, where population shifts were large, infrastructure damage was widespread and long-lasting, and even businesses that were not directly damaged by wind and flooding were affected by shifts in demand and disruptions to the supply chain.
} 
One recent paper that, like ours, straddles the literatures on disasters and financing is Hosono, Miyakawa, Uchino, Hazama, Ono, Uchida, and Uesugi (2012), which uses detailed firm-level data to estimate the impact of the 1995 Kobe earthquake on the supply of loans. That paper finds that firms whose headquarters were located outside the damaged area but which had borrowing relationships with banks located inside the damaged area fared worse than undamaged firms borrowing from undamaged banks. While that paper's findings underscore the importance of lending relationships to firm performance, our paper is agnostic about the mechanism by which credit favors older and larger firms. Instead, we focus on the selection effect of storm damage and on its disproportionate impact on young and small businesses.

The rest of the paper is organized as follows. Section 2 provides background information on hurricane Katrina's impact and the institutional response it generated. Section 3 describes our data in detail. Section 4 presents stylized facts from our data about the impact of storm damage to help guide our analysis. Our analysis of exits and a discussion of possible explanations are in Section 5. We discuss some implications of our findings in Section 6.

\section{Katrina's Effect on the Mississippi Coast}

Hurricane Katrina was the most damaging hurricane of the particularly active 2005 hurricane season. Katrina struck several locations in Florida before veering into the Gulf of Mexico and making landfall again in New Orleans on August 29, 2005 as a Category 3 hurricane. Katrina caused damage in several states, including Alabama and Florida, but the most severe damage to businesses was in Louisiana (primarily due to flooding) and along the Mississippi coast (primarily due to high winds and storm surge). Storm surges of 24-28 feet along the Mississippi coast reached as far as 12 miles inland, causing severe flooding (Knabb, Rhome, and Brown, 2005, p. 9), and the storm spawned at least 24 tornados (Federal Emergency Management Agency, 2006). In Louisiana, flood waters did not completely recede for several 
weeks.

Katrina's damage in Louisiana was widespread and caused large-scale population relocations and destruction of infrastructure. The population relocation created significant and persistent demand shocks; population in many of the parishes has yet to recover. In the hospitality industry, which is a major focus of our paper, infrastructure damage also reduced tourism, exacerbating the demand shock. Because it is difficult if not impossible to compare the consumption patterns of the displaced and remaining populations it is not possible to separately identify demand and cost shocks in Louisiana. ${ }^{3}$

To alleviate these problems the present study focuses on Mississippi. Infrastructure damage in Mississippi was for the most part limited, localized, and short-lived, and population loss was much more limited and short-lived. Because of the localization and short life of most infrastructure damage, we minimize confounding demand and infrastructure shocks that might otherwise bias estimates of the effects of damage to specific businesses. Figure 1 shows a map of Mississippi, highlighting the four counties that were most affected by hurricane Katrina.

Given our concern with the impact demand shocks have on the relative activity of large and small firms it is important to gauge the extent of such shocks in Mississippi. A first-order measure of demand is population. Unlike in Louisiana, Mississippi's population remained largely in place in the aftermath of Katrina. Table 1 lists the 2000 and 2010 population in the affected counties and the rest of the state. Population changes between 2000 and 2010 were generally modest in Mississippi. The exception is Stone County, which saw a population gain of nearly $27 \%$. Stone County is very small, however, and accounts for fewer than $0.5 \%$ of our observations. ${ }^{4}$

\footnotetext{
${ }^{3}$ Two recent studies of the effects of Katrina on Louisiana residents are Deryugina, Kawano, and Levitt (2013) and Groen, Kutzbach, and Polivka (2013).

${ }^{4}$ By contrast, Census data show that St. Bernard, Cameron, and Orleans parishes, the most affected parishes in Louisiana, each lost more than a third of its population between 2000 and 2010, while other Louisiana parishes experienced large population gains due to the relocation of evacuees.
} 
A second important indicator of economic recovery is the local unemployment rate, which rose in Hancock, Harrison, and Jackson counties in 2005 and 2006, but by 2007 had returned to its pre-storm levels (Sayre and Butler, 2011).

Another indicator of economic activity, especially relevant for the hospitality sectors including restaurants and hotels, is passenger air traffic. Figure 2 shows the dramatic decline and the recovery of the number of air passengers traveling to and from New Orleans and Biloxi over the period 2005-2010.5 Passenger air travel to and from New Orleans declined by almost three log points between August and September 2005, and had only recovered to approximately $85 \%$ of its original level by the end of 2010 . The initial shock was smaller at the Gulfport-Biloxi airport, and the recovery was complete within a few months.

The quick recovery of the Mississippi coast depended heavily on two sectors, military and casinos. Keesler Air Force Base in Biloxi, just a few blocks from the water, was heavily damaged by the storm, and at first there was some uncertainty about whether it would be rebuilt. This uncertainty was resolved within three weeks of the hurricane, when Air Force Secretary Pete Geren visited the base and promised to spend a billion dollars to fully restore it. The casinos, which had been barred from land and operated on floating barges, presented a bigger challenge, as they threatened not to rebuild unless they were allowed on land. Their threat was heeded: a month after the storm, on September 30, 2005, a controversial land-based casino bill made it through the Mississippi legislature (Smith, 2012, pp. 218-231). These two events, the Federal government's commitment to rebuilding Keesler and the casino bill, sealed the return of the Mississippi gulf coast.

Business recovery was also aided by a web of government programs that provided poststorm support to residents and business owners affected by the storm. The most substantial program directed at business owners was a loan program administered by the Small Business Administration (SBA). Access to this program was not restricted to small business and it

\footnotetext{
${ }^{5}$ The figure was calculated using monthly data from the Bureau of Transportation Statistics, available at http://www.transtats.bts.gov/DL_SelectFields.asp?Table_ID=258. Accessed December 12, 2013.
} 
offered lower interest rates and longer terms than conventional loans. ${ }^{6}$ In addition, Mississippi offered small businesses in the worst-hit areas a 180-day, no-interest loan program; by the end of 2005, 392 small businesses had taken loans totaling over $\$ 9$ million under this program (Kast, 2005).

Despite this and sundry other programs, the General Accounting Office (GAO) concluded that small businesses experienced credit- and funding-related difficulties recovering from the disasters. Among the explanations provided were the loss of financial documents, which limited businesses' ability to apply for SBA and other loans, as well as increased costs of doing business due to insurance payments and the need to repay recovery-related debts (General Accounting Office, 2010). In other cases, business owners simply declined to take out loans even with low or no interest. Smith (2012, p. 232) documents the uneven recovery in which larger and older firms took the lead and documents that in 2007, even as casinos recovered, "membership in the Gulf Coast Chapter of the Mississippi Hospitality and Restaurant Association stood at only 70 percent of its pre-Katrina strength [and] few of the mom-and-pop motels and eateries that once dotted Highway 90 had rebuilt."

\section{Data}

The primary building block in our analysis is the Census Bureau's Longitudinal Business Database (LBD). The LBD is a longitudinal database covering all employer establishments and firms in the U.S. non-farm private economy (for more information on the LBD, see Jarmin and Miranda, 2002). We use data from the LBD to track the activity and outcomes of all retail stores, restaurants, and hotels operating in Mississippi between 2002 and 2010. Hurricane damage is narrowly localized with some areas devastated while other in close

\footnotetext{
${ }^{6}$ The SBA approved over 13,400 disaster loans for businesses of all sizes affected by the hurricanes from fiscal years 2005 through 2009, and more than 10,700 of these loans were identified as having assisted small businesses. 2,362 of these small business loans went to Mississippi. Most of these loans were specifically directed to small businesses that were not able to obtain credit elsewhere (Small Business Administration, 2008).
} 
proximity are spared the impact. We use geo-spatial damage maps from FEMA to determine which establishments were directly hit by Katrina's winds or storm surge.

We limit our analysis to retail and restaurant businesses and hotels and other accommodation facilities (including casinos) for several reasons. ${ }^{7}$ First, they represent a very large share of the local economies in the affected counties, approximately ten times as large as manufacturing. This is important since affected areas are small and we need sectors with enough data to conduct the analysis. Second, unlike many other service industries and some non-service industries (e.g., construction), the location of the business is non-fungible. Whereas a lawyer may continue to provide legal services and a janitorial firm may continue to provide cleaning services even if the main office is destroyed, stores, restaurants, and hotels provide their services at the business address and cease operations when that location is destroyed. Finally, selected retail and services serve local (and tourist) demand. Demand for products in other sectors such as manufacturing may extend beyond the local area in ways that we do not observe, making it hard to determine the relative effect of demand and cost shocks for these businesses.

A few aspects about the construction of the LBD are relevant for our purpose. The LBD is constructed from several sources including administrative business payroll filings and Census collections. ${ }^{8}$ These filings are processed by the Census Bureau on a flow basis as they are received. Establishments in the LBD are defined to be "active" if they report positive payroll to the Internal Revenue Service (IRS) for any part of the year. Following Katrina, the IRS postponed tax filing deadlines several times, including waiving penalties and late fees, of individuals and businesses in affected areas. The original relief order, IRS News Release IR-2005-84, extended the filing deadlines by 45 days to taxpayers in 31 Louisiana parishes,

\footnotetext{
${ }^{7}$ These business establishments correspond to NAICS 44-45 and 721-722. We exclude from the analysis non-store retailers such as catalog companies and vending-machine operators, NAICS 454, as well as caterers and mobile food-service providers, NAICS 72232 and 72233.

${ }^{8}$ Administrative records are enhanced with Census collections to identify meaningful economic units of interest such as establishments and firms.
} 
15 Mississippi counties, and three Alabama counties; later revisions increased the number of counties and parishes relieved and ultimately extended the deadline by another full year. Further extensions to April 2007 were also available. These filing extensions naturally cause disruptions in the flow of transactions recorded by the Census in a given year and could lead us to attribute an establishment exit when none exists. However, late filings are recorded by the Census Bureau as amendments to prior year records when they are reported by the IRS. These amendments are recorded up to two years after the original filing year. We rely on these late filings and amendments to fill in reporting gaps and to identify late filers. However, because some businesses filed even later (or perhaps not at all), we expect some reporting gaps for establishments that were otherwise active for at least part of this year, particularly for smaller firms. To ensure that we correctly measure exits against the true population of businesses, we use 2004 data as our baseline, and compare 2004 to 2006 for our short-run analysis, 2006 to 2008 for the medium-run analysis, and 2008 to 2010 for the long run.

A measure of productivity at the establishment level is derived from the 2002 Census of Retail Trade (CRT) and the 2002 Census of Accommodation and Food Services (CFS), which provide establishment revenue information. In the absence of information on other inputs, such as cost of materials and capital, we calculate productivity as the log of the ratio of the establishment's annual revenue to employment. ${ }^{9}$ To control for productivity, we limit our analysis to continuers that had existed in 2002.

We supplement the LBD/CRT/CFS with data from the integrated LBD (ILBD), which follows businesses with revenues but no payroll. The ILBD is described in detail in Davis, Haltiwanger, Jarmin, Krizan, Miranda, Nucci, and Sandusky (2009). Non-employer businesses have firm identifiers but no establishment identifiers since an establishment is defined

\footnotetext{
${ }^{9}$ Establishment revenue is not available in annual data sets, but only in the quinquennial Economic Censuses. Employment is measured as of the week of March 12, 2002. We drop the top and bottom 1\% of our productivity measures to remove the influence of outliers. Our ratio measure is also used in Foster, Haltiwanger, and Krizan (2002) and Doms, Jarmin, and Klimek (2004). Basker (2012) uses the ratio of revenue to payroll as an alternative measure of productivity. See Foster, Haltiwanger, and Krizan (2002), Haskel and Sadun (2009), and Betancourt (2005) for further discussion.
} 
by the Census Bureau as the location of employment. If a firm disappears from the LBD, having laid off or lost all its employees in a given year, we search for that firm in the following year's ILBD to determine whether it continued to earn revenue. Approximately $7 \%$ of businesses that lose their employees retain a non-employer status two years later. A small number of those return to employer status in later years.

The resulting enhanced LBD is an establishment-level dataset that includes both firm characteristics and transition events into non-employer status. An establishment in the LBD is the physical location in which business is conducted and a firm is the legal entity with operational control. Establishments that belong to the same firm are linked in the data via a firm identifier. The LBD tracks the activity of these firms over time, including the opening and closing of establishments and acquisitions and divestitures of pre-existing establishments. Our data thus allows us to identify exits in the form of shutdowns (the establishment never reopens), but also exits as transitions into the non-employer universe, and exits in the form of ownership changes. In most of the analysis below, we define an establishment as a continuer from year $t$ (the "base year") to year $t^{\prime}>t$ if the establishment had positive payroll in both years or had positive payroll in year $t$ and again in some later year $t^{\prime \prime}>t^{\prime}$, and as an exiter if it had positive payroll in year $t$ and no payroll in year $t^{\prime}$ or thereafter. This definition of exit is conservative in that periods of temporary inactivity are not considered exits. Put differently, we identify permanent exits and exclude from the analysis transitory periods of inactivity. The sample for our analysis of exits between 2002 and 2004 and between 2004 and 2006 includes all establishments with payroll in the base year. For the analysis of exits between 2006 and 2008 and between 2008 and 2010 we restrict the sample to establishments that had payroll in 2004 and had not exited by the relevant base year.

The firm identifier helps us determine the age and size of the entity that owns the establishment. ${ }^{10}$ Our measure of firm size is the number of establishments the firm operates

\footnotetext{
${ }^{10}$ We compute firm age using the same methodology as in Haltiwanger, Jarmin, and Miranda (2013), which is also used in the construction of the Business Dynamics Statistics (BDS); see http: //www. census .
} 
nationwide. The firm identifier also allows us to track ownership changes.

For robustness checks, we have both expanded and narrowed the definition of exit in several ways. First, in some robustness checks we have expanded the definition of exit to include establishments whose payroll fell by more than $90 \%$ between years $t$ and $t^{\prime}$. Conversely, we have also restricted the definition of exit to exclude cases of establishments that cease to report payroll but report revenue as non-employers in year $t^{\prime}$ or thereafter.

In our sample approximately $18 \%$ of establishments that had payroll in 2004 are no longer in business in 2006; $14 \%$ of those that continue to 2006 are no longer in business by 2008; and $13 \%$ of establishments still active in 2008 are no longer in business by 2010 . These exit rates increase (decrease) by 1-3 percentage points when we expand (restrict) the definition of exit, depending on the year.

We geocode establishments using Geographic Information System (GIS) tools to assign latitude and longitude based on the business's address. The Census Bureau spends considerable resources ensuring that the business address on file corresponds to the physical address. It requires businesses responding to a census or a survey form to provide the physical address of all their establishments. Establishments never covered by a census or a survey are assigned their mailing address as identified through their administrative filing forms. Beginning in 2007, the Census Bureau's Geography Division has provided geocoding for all business establishments. For establishments still in operation in 2007 we use the Geography Division's geocodes. For establishments that exited prior to 2007 we use ArcGIS's "address locator" geocoding tool to attach latitude and longitude information to business addresses. ArcGIS provides a normalized score, out of 100, to indicate the quality of the geocoding; we keep only geocodes scored 60 or above. In a small number of cases the business address may represent the address of an accountant or other hired provider who assists the business with

gov/ces/dataproducts/bds/. Firm age is defined as the age of the oldest establishment in the firm when a new firm identifier first shows up in the database. The firm then ages naturally regardless of merger and acquisition activity as long as the firm continues to exist as such. Firm age is censored from above because we do not know the exact age of firms that existed in 1976, the LBD's first year. 
those forms. To minimize this problem, we removed 230 businesses whose addresses were identical to addresses provided by accounting or bookkeeping firms.

Not all addresses are of the necessary quality to be able to geocode down to latitude and longitude successfully. Incomplete addresses and non-standard addresses (e.g., rural routes or PO Box addresses) are the main reasons for failures. Rural areas are known to be particularly problematic in this regard. For 2004, in each of the four Mississippi counties that experienced direct damage from Katrina - Hancock, Harrison, Jackson, and Stone Counties - we were able to geocode more than $85 \%$ of establishments. Table 2 lists the number of geocoded establishments in each of the four affected counties in comparison with the rest of the state. ${ }^{11}$

Table 3 compares summary statistics of establishment and firm characteristics for geocoded and non-geocoded establishments in the four affected counties in 2004. Compared to nongeocode establishments, geocoded establishments are on average about one year younger and more likely to belong to single-unit firms.

Damage information comes from FEMA and is described in detail in Jarmin and Miranda (2009). Using remote-sensing technology, FEMA classified damaged areas over the period August 30 to September 10 using a four-tier damage scale: limited, moderate, extensive, and catastrophic. ${ }^{12}$ We reduce this to a two-tier scale, combining "extensive" and "catastrophic" into one category and "limited" and "moderate" into a second category. In practice, there was very little extensive damage so almost all of the damage we classify as extensive/catastrophic is catastrophic. Critically, damage designations are not based on

\footnotetext{
${ }^{11}$ These geocoding rates are similar to those obtained by Geography Division.

${ }^{12}$ FEMA's damage classification defines damage categories as follows. Limited Damage: Generally superficial damage to solid structures (e.g., loss of tiles or roof shingles); some mobile homes and light structures are damaged or displaced. Moderate Damage: Solid structures sustain exterior damage (e.g., missing roofs or roof segments); some mobile homes and light structures are destroyed, many are damaged or displaced. Extensive Damage: Some solid structures are destroyed; most sustain exterior and interior damage (roofs missing, interior walls exposed); most mobile homes and light structures are destroyed. Catastrophic Damage: Most solid and all light or mobile home structures destroyed.
} 
insurance claims. However, because FEMA's remote-sensing maps focus primarily on developed areas, we may under-estimate the damage in less-developed areas.

Following Jarmin and Miranda (2009), we add the FEMA damage information to the geocoded enhanced LBD to obtain, for each geocoded establishment, the FEMA classification of the location containing that establishment. Figure 3 shows an area on the border of Harrison and Hancock counties in Mississippi in which storm damage was widespread and highly variable. Each gray dot on the map represents a single business establishment. ${ }^{13}$ Establishments in red (diagonally cross-hatched) areas were extensively or catastrophically damaged, while those in green (horizontal and vertical cross-hatched) areas were damaged to a limited or moderate degree. Establishments in the white areas were physically undamaged. In addition, a handful of business establishments were located in areas in Mississippi that still had standing water as of September 6, 2005 (one week after the storm). These areas are indicated in the figure in blue (diagonally lined) but are excluded from our analysis due to the very small number of establishments impacted by flooding; none of our results are sensitive to this exclusion.

Table 2 provides 2004 summary statistics for the four affected counties and an aggregated "rest of state" category. Approximately 350 establishments were in areas later designated by FEMA as having endured extensive or catastrophic wind damage, and 350 more were in areas later designated as having suffered limited or moderate damage. We refer to all of these establishments as "damaged." The last two columns in Table 2 provide the approximate percentage of establishments in each of the designated areas. Very small cells are suppressed to comply with Census Bureau disclosure requirements.

Table 4 shows pre-storm summary statistics for the 2004 cross-sections of establishments in our data. We show the average value for establishments located in areas that were later damaged and those located in areas that were undamaged. For all the variables listed — firm

\footnotetext{
${ }^{13}$ These dots were "jittered" in compliance with Census Bureau disclosure procedures to prevent identification of particular establishments.
} 
size (number of establishments in firm as well as a single-unit firm indicator), firm age, establishment size (employment), and establishment age — the differences between the damaged and undamaged areas are both small and statistically insignificant. The only statistically significant difference between damaged and undamaged establishments is that damaged establishments have slightly lower measured pre-storm productivity. For this reason, we control for productivity in all the reported regressions in the paper.

Finally, approximately $13 \%$ of our sample consists of sole proprietorships, for which additional data are available. Specifically, we are able to match sole proprietorships to their owners' demographic information from the 2000 Population Census 100\% ("short-form") file. In an extension of our main results, we investigate the role of the business owner's gender on establishments' ability to survive storm damage, and on their post-storm behavior. Table 5 provides summary statistics for the sole-proprietor sample in 2004. As in the earlier tables, the table shows data for undamaged and damaged establishments. We omit firm-size measures because the 99th percentile sole proprietorship in our sample operated just one establishment. Compared to the full sample of establishments, which had 18 employees on average, sole proprietorships in our sample have fewer than five employees. They are on average 13 years old, five years younger than the average of the full sample. Approximately $30 \%$ of sole proprietorships in our sample are owned by women. No establishment- or firmlevel characteristics differ statistically by damage classification within this sample.

\section{Stylized Facts}

In this section we provide basic facts regarding the effect of the hurricanes on the economic activity of the region to motivate the empirical analysis.

We start by taking the universe of retail, restaurant, and hotel establishments in Mississippi with positive payroll in 2004 and a geocoded address. We partition these establishments into two subsets: those located in Hancock, Harrison, Jackson, and Stone counties (the coun- 
ties in which FEMA designated damaged areas); and those located elsewhere in Mississippi. Figure 4 shows the log change in the number of restaurants, stores, and hotels that had positive payroll activity in 2004 in these two parts of the state from 2004 to 2010. The solid line, which represents the undamaged counties, trends down due to normal attrition (exit) by establishments in these sectors at roughly 9\% per year. By 2010, approximately $45 \%$ of business establishments that operated in 2004 had exited. The dashed line, showing the same trend for the four counties with significant damage, follows a similar downward trend, with the exception of one year: between 2005 and 2006, the exit rate in the damaged counties exceeded that in undamaged counties by nearly 15 percentage points. The following year, exit rates for establishments that had survived to 2006 were again very similar across the state.

Next, we hone in on the four damaged counties and partition those further into areas that were designated by FEMA as undamaged, areas designated as having experienced limited or moderate damage, and areas designated as having experienced extensive or catastrophic damage. Figure 5 shows the log change in the number of continuing restaurants, stores, and hotels with positive payroll activity in each of these areas since 2004 . While exit rates in the undamaged areas of the four counties are nearly indistinguishable from exit rates elsewhere in the state, this is not the case for the damaged areas of these counties. The immediate effect of Katrina was an approximately 30\% reduction in the number of active establishments in the most heavily damaged areas, and a smaller decrease in the number of establishments in the limited/moderate damage areas. Exit rates for these continuing establishments continue to diverge from 2006 to 2007, but appear to stabilize thereafter.

Having established that Katrina damage had a measurable effect on business establishment's survival, we turn to estimating exit dynamics as a function of relevant firm characteristics. 


\section{$5 \quad$ Exits and Firm Characteristics}

Hurricane Katrina provides us with a laboratory in which to test whether smaller and younger firms are less limber in response to a specific, well-measured, and narrowly inflicted cost shock compared with a control group that does not experience the direct cost shock but is otherwise similar.

\subsection{Firm Age}

We estimate the following cross-sectional linear probability model of exit for business establishment $i$ located in county $j(i)$ and in six-digit NAICS $n(i)$ :

$$
\begin{aligned}
\text { Exit }_{i}=\alpha_{j(i)} & \gamma_{n(i)}+\sigma \ln (\text { FirmAge })_{i}+\sigma_{0} \mathbb{I}\left(\text { FirmAge }_{i}=0\right)+\delta \text { Damage }_{i} \\
& +\beta \ln (\text { FirmAge })_{i} \cdot \text { Damage }_{i}+\beta_{0} \mathbb{I}\left(\text { FirmAge }_{i}=0\right) \cdot \text { Damage }_{i} \\
& +\eta \ln \left(\text { FirmSize }_{i}+\pi \cdot \operatorname{Prod}_{i}+\phi \cdot \operatorname{Prod}_{i} \cdot \text { Damage }_{i}+\varepsilon_{i}\right.
\end{aligned}
$$

where Exit is a binary variable defined over a two-year horizon, e.g., from 2004 to 2006. In

that case Exit is an indicator that equals 1 if the establishment, having had payroll in 2004, had permanently exited the employer universe by 2006. The sample includes all geocoded Mississippi retail, restaurant, and hotel establishments with positive payroll in 2004 and productivity estimates from the 2002 Economic Census.

On the right-hand side, $\boldsymbol{\alpha}$ is a county fixed effect intended to capture different area-wide exit probabilities due to overall demand and infrastructure shocks. As noted in Section 2, post-Katrina population relocation and infrastructure damage were much more limited in Mississippi than in Louisiana, but these events nevertheless represented demand shocks for local businesses. The county fixed effects are intended to control for these shocks. Even within these smaller areas it is likely that relocation affected some sub-populations more than others, but as long as the consumption patterns of the relocated population do not 
reveal a preference towards business of a specific size or age our estimates of the storm effect by business characteristics should not be biased.

The six-digit NAICS fixed effect $\gamma$ captures differences in exit rates across 110 types of businesses due to different growth and churn rates across sectors. All variables are evaluated in the regression's base year; e.g., for exit between 2006 and 2008 we use the 2006 values for variables. FirmAge is measured as the age of the firm operating establishment $i$. Because we do not want to lose establishments belonging to new firms when we take the log of firm age, we arbitrarily set $\ln (0)=0$ and add an indicator for establishments with age zero; the coefficient on $\mathbb{I}($ FirmAge $=0)$ captures the differential exit probability of an establishment belonging to a brand-new firm (thus the establishment is new itself) relative to an establishment belonging to a one-year-old firm. ${ }^{14}$

The firm-age variables capture different exit rates due to unobserved productivity effects as well as differences in resources (financial and otherwise) available to more established firms but not captured by our remaining controls. Damage is a vector of two damage indicators: limited or moderate damage and extensive or catastrophic damage. The interaction between FirmAge and Damage captures the differential exit rates for establishments in damaged areas by firm age.

We include a few additional covariates that are correlated with exit. Larger firms, like older firms, are selected for better management, access to resources, and other correlates of survival. We control for these types of effects with FirmSize, which represents the number of establishments owned by the firm that operates establishment $i$. We also control for establishment productivity, Prod (the ratio of revenue to employment in 2002), for two reasons. First, productivity, like firm size, is a known correlate of firm age, and we want to isolate as much as possible the effect of age as distinct from productivity and size. For the

\footnotetext{
${ }^{14}$ This variable only appears in the 2002-2004 regressions, since the minimum age of an establishment in 2002 is zero. By 2004, all establishments with productivity estimates from the 2002 Census are at least two years old.
} 
same reason we also include interactions of productivity and the damage vector, to capture the type of "creative destruction" that occurs when more productive firms withstand a shock that less-productive firms cannot withstand. Second, measured pre-storm productivity is slightly lower for damaged establishments than undamaged ones (see Table 4), and we do not want to overstate the effect of damage on establishment exit.

The error term $\varepsilon$ is clustered at the county level. Clustering accounts for the fact that business survival is interdependent across the county.

We include all establishments in Mississippi in the retail, restaurant, and hotel sectors as controls. However, because we have county fixed effects in all regressions, the coefficients on the two damage variables are identified within county: they represent the differential exit rates of damaged establishments relative to the average exit rate of undamaged establishments in the same county. Establishments in other counties are used to identify control variables, including the 110 NAICS fixed effects and firm and establishment characteristics. The coefficients on the interaction terms of firm age and damage are identified within county, but their magnitude is also affected by the main firm-age effects, which depend in part on the control group. We have also estimated all the regressions using alternative control groups, including only the four counties with direct damage (Hancock, Harrison, Stone, and Jackson), and an eight-county region that includes those four counties and four adjacent counties (Pearl River, Forrest, Perry, and George). Our estimates are not sensitive to the choice of control group.

The identifying assumption in our analysis is that, within the counties affected by Katrina, the precise path of the storm and therefore the damage inflicted was random. While businesses were clearly not damaged due to any underlying characteristics such as size, productivity, profitability, etc. (the hypothesis of God's wrath notwithstanding), it could still be that damage was assigned non-randomly, that is, in a way that is correlated with underlying 
characteristics (both observable and unobservable). ${ }^{15}$ Table 4 in Section 3 , however, provides reassurance in that observables are distributed similarly in the treated (damaged) and control (undamaged) samples. The only exception is productivity, which is slightly lower on average for damaged establishments; we control for productivity both directly and interacted with the two damage categories. Finally, we assume that county and detailed-industry fixed effects fully capture demand shocks following the storm. The remaining differences between damaged and undamaged establishments can then be attributed to their differential recovery costs.

To further address the concern that unobserved variables may not be distributed similarly in the two samples, we also estimate all our regressions on a pre-storm period, for which we analyze exits between 2002 and 2004. Exits over this period could not have been affected by the 2005 storm, so any relationship we find between exit over this period and location in a future storm-damage zone must reflect location-specific unobserved variables that influence survival rates. These estimates therefore establish a baseline against which we can compare the post-storm regression coefficients to make causal interpretations.

Although the setting is cross-sectional and not a panel, the estimates of the impact of the storm can be interpreted as difference-in-difference estimates in the sense that we focus on the estimate of impact of the interaction of firm age and damage while controlling for the two effects separately. Comparing our estimates for the post-storm period to the pre-storm estimates from 2002-2004 provides an indirect third difference.

Estimates from these regressions are presented in Table 6. We estimate four regressions, each over a different two-year horizon. The first estimates the probability of exit between 2002 and 2004. This is our pre-storm baseline. The second estimates the probability of exit between 2004 and 2006 (post-storm short run). The third estimates the probability of exit between 2006 and 2008, and the last between 2008 and 2010 (post-storm medium and

\footnotetext{
${ }^{15} \mathrm{~A}$ similar issue having to do with using geographic variation to identify the impact of Wal-Mart is discussed in some detail in Basker (2006) and Basker and Noel (2009).
} 
long runs respectively), in both cases conditioning on the establishment having existed and having had positive payroll in 2004.

Column (1) reports the pre-storm results. As expected, establishments belonging to older and/or larger firms and establishments with higher productivity have systematically lower exit rates than establishments in younger and smaller firms and those with lower productivity. ${ }^{16}$ These effects are all significant at the $1 \%$ level. The only other significant coefficient in the pre-storm regression (at the 10\% level) is on the interaction of the indicator for (future) limited/moderate damage and productivity.

In column (2) we estimate the probability of exit between 2004 and 2006, the period that includes Katrina's landfall and its immediate aftermath. The main short-run effect of the storm is an increase in exit probability in areas that experienced extensive and (primarily) catastrophic damage. Ceteris paribus, establishment in these areas had a 54-percentage-point increased exit probability between 2004 and 2006 relative to undamaged establishments in the same counties. There is no statistical difference between the exit probabilities of undamaged establishments and those that suffered limited or moderate storm damage. Firm age and firm size continue to matter: for example, doubling an owning firm's age is associated with a 2.2 percentage-point decrease in an undamaged establishment's probability of exit, as it did prior to the storm. Higher-productivity establishments are still less likely to exit, but the effect is muted relative to the pre-storm period, possibly because productivity is measured using the 2002 Census, so, as time goes on, it is measured with more noise.

In the immediate aftermath of the storm both firm age and establishment productivity act to diminish the negative effect of storm damage. The same doubling of a firm's age described above now decreases exit probability in the areas most heavily damaged by Katrina by an additional 4.5 percentage points, a tripling of the effect of age on exit. Put differently,

\footnotetext{
${ }^{16}$ These patterns are consistent with empirical studies that show there is considerable variation in establishment exit by size and age even after controlling for productivity differences. See Doms, Dunne, and Roberts (1995) for a good example and additional references.
} 
all establishments located in damaged areas exit at higher rates but the exit-rate differential between young and mature businesses is three times higher in damaged areas. This result is consistent with Fort, Haltiwanger, Jarmin, and Miranda's (2013) finding that young firms are also more sensitive to business-cycle shocks and housing-price shocks.

What drives this differential effect of storm damage by firm age? One possibility is that age is a proxy for profitability. If mature firms are more productive and better managed, it may be easier for them to absorb this unforeseen cost shock and thus rebuild and reopen. If the coefficient on age is picking up some of the effect of profitability, above and beyond what we can control for using the establishment's 2002 productivity, then the differential effect of damage on exit may be efficient, in the spirit of Caballero and Hammour's (1994; 1996) "cleansing" effect of recessions. Establishments that exit are those whose rebuilding costs exceed their lifetime present discounted value of profits. It is a Schumpeterian type of exit in that the least productive units are scrapped and factors released to alternative uses. Alternatively, young firms may face financial constraints beyond those faced by older firms due to imperfections in financial markets or lack of internal funds. If young firms' costs of accessing financial resources and credit are, in fact, higher, limiting their ability to rebuild otherwise-profitable operations, we could be observing inefficient liquidations of otherwise valuable production units. Firm age may also be correlated with other factors that increase the marginal cost of rebuilding, including access to information about the market, labor selection and training costs, managerial resilience, and material costs. Attitudes towards risk, which may change over a firm's life cycle, could also affect the optimal decisions of firms. Finally, young and old firms could have different incentives, leading them to make different choices with respect to rebuilding.

The next two columns provide some insight into the relative important of these alternative explanations. In the third column we estimate the probability that a business that 
existed in 2004 and was still in operation in 2006 exited between 2006 and $2008 .{ }^{17}$ In this regression we can no longer treat the coefficients as causal under the assumptions we applied in the first two columns because the selection criterion for inclusion in the sample is having survived to 2006. We take this selection bias into account when interpreting the coefficients.

The most striking difference between the 2004-2006 and the 2006-2008 regressions is that the direct effect of having been hit by extensive or catastrophic damage in 2005 disappears entirely in the latter period, conditional on having survived to 2006. The direct effects of firm age and firm size are virtually unchanged. ${ }^{18}$ The direct effect of 2002 productivity continues to be significant. However, the interaction of age and damage is now positive, large, and statistically significant. While exit rates of undamaged establishments decrease with firm age, this effect is reversed in areas recovering from extensive or catastrophic storm damage.

This effect continues into the next period, as seen in the final column of Table 6 . This column uses exits between 2008 and 2010 as the dependent variable. The sample includes establishments that have either survived continuously since 2004 as well as those that re-entered between 2004 and 2008. The exit rate in areas that experienced extensive or catastrophic damage years earlier is nearly 25 percentage points lower than in areas that did not experience any storm damage. In other words, conditional on surviving to 2008, businesses in damaged areas are much more resilient than those that were not tested by Katrina's winds. And while the direct effect of age is stronger than in the other regressions, the coefficient on the interaction between age and damage continues to have the opposite sign and to be larger, in absolute terms, than the direct effect.

To summarize, while the short-run effect of Katrina was large and negative, those establishments that were damaged but returned to operation proved more resilient than their

\footnotetext{
${ }^{17}$ Given the amount of damage experienced by firms in catastrophically affected areas, we expect these firms to have had periods of inactivity during the rebuilding phase. Analysis of quarterly payroll data indicates periods of inactivity for a majority of firms in these areas immediately after the storm hit but a quick return to operations for many.

${ }^{18}$ Firm age is now measured as of 2006. As all establishments are continuers at least since 2004, there is no need for the age-zero indicator in the later regressions.
} 
undamaged counterparts in the long run. Surviving the storm and rebuilding is a signal of a business's commitment, profitability, and resourcefulness. However, we find this signal is much stronger for establishments in young firms than for those belonging to older, more established, firms, suggesting that factors besides profitability may have been at work, leading to exits of some otherwise-viable businesses. The fact that exit rates in the post-storm period are relatively high for surviving mature firms indicates that they have become less competitive vis-à-vis the most resilient (surviving) young firms.

We have checked the robustness of these results in several unreported regressions. Changing the sample of controls to omit counties immediately adjacent to the damaged counties or even to omit all undamaged counties does not change the results in any meaningful way, although standard errors on some coefficients increase. Similarly, adding establishment-level covariates (base-year establishment age and employment) to the regressions has no impact on the qualitative patterns although coefficient magnitudes change somewhat across specifications. Finally, we have estimated the regression nonlinearly using a probit model; the results are again qualitatively unchanged.

A final robustness check addresses a purely measurement-driven explanation for the results we have reported: that establishments belonging to older firms could take longer to shut down in an orderly fashion and to that end may hold on to key employees for a short period. (They could also retain employees for a short period as a gesture of goodwill towards valued employees who have been with the company for a long time.) To address this concern, we redefine exiters to include not only establishments that go from positive to zero payroll but also those whose payroll is reduced by $90 \%$ or more, but remains positive, as long as we observe them exiting the employer universe at a later date. The redefinition effectively moves exits previously observed between 2006 and 2008 or between 2008 and 2010 to an earlier period. Although this adjustment does weaken the pattern of coefficients we reported 
above, the pattern remains both statistically and economically significant. ${ }^{19}$ Thus, it seems that this explanation does play a part in our findings, but it does not explain them away.

\subsection{Firm Size}

As with firm age, we also expect firm size to be correlated with the firm's ability to survive a shock. We test the robustness of our age results above by replacing age with size, as follows:

$$
\begin{aligned}
\text { Exit }_{i}= & \alpha_{j(i)}+\gamma_{n(i)}+\sigma \ln \left(\text { FirmSize }_{i}+\delta \text { Damage }_{i}+\beta \ln \left(\text { FirmSize }_{i} \cdot \text { Damage }_{i}\right.\right. \\
& +\eta \ln \left(\text { FirmAge }_{i}+\eta_{0} \mathbb{I}\left(\text { FirmAge }_{i}=0\right)+\pi \cdot \operatorname{Prod}_{i}+\phi \cdot \operatorname{Prod}_{i} \cdot \text { Damage }_{i}+\varepsilon_{i}\right.
\end{aligned}
$$

where FirmSize is measured by the number of establishments operated by the firm that owns establishment $i$, and range from one (for single-unit firms) to several thousand. Firm size has a technical advantage over firm age, in that it is never censored and can take on any integer value. However, recent evidence suggests that firm size is a weaker indicator of a firm's ability to withstand a serious shock (Haltiwanger, Jarmin, and Miranda, 2013). All other variables are as defined in the previous section, and we continue to include firm age as a control.

Estimates from regressions for the same four time periods as above are shown in Table 7. Across all the regressions, larger firms exit at lower probabilities. The effect of doubling a firm's size appears smaller than the effect of doubling a firm's age in Table 6, but the coefficients are not directly comparable since firm size takes values over a much larger range.

The overall pattern that emerges from these regressions is similar to that using firm age. We see both an immediate effect of extensive/catastrophic storm damage, which substantially

\footnotetext{
${ }^{19}$ The absolute value of the coefficient on the interaction of firm age and extensive/catastrophic damage falls by three percentage points, from 0.065 to 0.036 , in the short run, but remains negative and significant at the $1 \%$ level; the medium-run coefficient on this interaction term falls from 0.119 to 0.089 but remains positive and statistically significant at the $1 \%$ level; and the long-run coefficient falls from 0.084 to 0.078 but also remains positive and statistically significant at the $1 \%$ level. Other coefficients are affected even less. The full results from these regressions are available upon request.
} 
increases exits in the short run (2004-2006), and a diminishment of this effect over several years (we no longer see a clear reversal of this effect in 2008-2010). In addition, while size provides a cushion against the effect of catastrophic damage in the short run, in the long run this cushion disappears. Again, the result is consistent with a higher-than efficient exit rate of establishments in firms with limited resources. These results are insensitive to changes in the control group, the definition of the exit variable, and functional form, as described in Section 5.1.

\subsection{Owner Gender}

The previous sections show that establishments belonging to younger and smaller firms, which are perhaps less resourceful or face higher costs of rebuilding, were much more likely to exit initially following Katrina-inflicted damage but that there was a "catch-up" effect for establishments belonging to larger and more mature firms. We have speculated that the heterogeneity in their dynamic response may be related to differences in the cost structure that are captured by the age and size variables, rather than a differential demand shock. In this section we examine this hypothesis further by focusing on the population of establishments that are organized as sole proprietorships. These businesses are uniformly small and so, to the extent that a demand shock favored large businesses in the initial aftermath of the storm, these businesses would have been similarly affected.

Our sample of sole proprietorships is small, about $15 \%$ of the total number of observations we use in the age and size regressions. However, because we are able to match ownerdemographics data for this subset of businesses, we are able to test whether the owner's gender is correlated with the ability of the business to weather Katrina's damage.

The literature on the relationship between owner gender and the success of a business is relatively small. Coleman and Robb (2009) find that, relative to men, women entrepreneurs start with significantly lower levels of financial capital and raise less debt and equity after start up. This result suggests that financial constraints may hinder female-owned businesses' 
ability to survive storm damage. In this regard, Blanchflower, Levine, and Zimmerman (2003) find evidence of limited gender-based lending discrimination. At the same time, Cole and Mehran (2001) report that female-owned businesses are generally younger and smaller than their male-owned counterparts; their owners are younger, less educated, and less experienced, which implies that female-owned businesses may be less profitable and/or resourceful, and therefore less likely to survive a cost shock. ${ }^{20}$

To test whether female-owned sole proprietorships are disadvantaged in the recovery process relative to male-owned sole proprietorships we estimate the following cross-sectional linear probability model:

$$
\begin{aligned}
\text { Exit }_{i}=\alpha_{j(i)}+\gamma_{n(i)}+\delta \text { Damage }_{i} & +\lambda \text { Female }_{i}+\mu \text { Female }_{i} \cdot \text { Damage }_{i} \\
& +\sigma \ln \left(\text { FirmAge }_{i}+\sigma_{0} \mathbb{I}\left(\text { FirmAge }_{i}=0\right)+\pi \cdot \text { Prod }_{i}+\varepsilon_{i}\right.
\end{aligned}
$$

where Female is an indicator for a female-owned businesses, and the coefficient $\lambda$ captures differential exit rates for such businesses. The coefficient $\mu$ captures the differential increase in exit probability for female-owned businesses due to severe extensive or catastrophic damage. We make several modifications to our earlier regressions due to the smaller number of observations and reduced power of the regressions. First, we no longer include county fixed effects due to sample size issues; instead, $\alpha$ is a single indicator that equals 1 if establishment $i$ was located in one of the four damaged counties. Second, we replace the six-digit NAICS fixed effects with four-digit fixed effects. Third, we include productivity only as a linear

\footnotetext{
${ }^{20}$ The literature on the relationship between race and financing and firm performance is larger and more conclusive. Historically, black entrepreneurs in the U.S. were more likely to use credit cards than other forms of finance. Chatterji and Seamans (2012) present evidence that black entrepreneurs are particularly vulnerable to limits on credit-card lending in the 1970s and 1980s, and Blanchflower, Levine, and Zimmerman (2003) show that in the 1990s, black-owned small businesses were twice as likely to be turned down for bank loans even after controlling for credit risk. More recently, Robb, Fairlie, and Robinson (2009) provide evidence from the Kauffman Firm Survey that suggests that black-owned businesses' access to capital has not improved in the 2000s. However, our sample includes very few black-owned businesses, limiting both the power of our regressions and our ability to report results without compromising Census confidentiality requirements.
} 
term, without interacting it with the damage vector. Finally, while we control for firm age, we no longer control for firm size, as the 99th percentile of firm size in this sample is one.

Results are shown in Table 8. In contrast with the results for the full population of businesses, here we see lingering effects of storm damage years after Katrina: exit rates for surviving businesses that we severely damaged continue to exceed their undamaged counterparts' exit rates as late as 2008-2010. We also find that small businesses owned by women were twice as likely to exit in the immediate aftermath of the storm. But while catastrophically damaged male-owned sole proprietorships continued to exit at very high rates between 2006 and 2008 relative to undamaged male-owned businesses, female-owned exits culminated early on. As in the previous sections, we find a reversal of the effect of storm damage on female-owned business in the medium and long runs.

As these businesses are overwhelmingly very small, we are not concerned about the possibility of bias due to delayed shut-downs as in the case of larger businesses. Rather, some of these businesses may let go of all their employees, transitioning to non-employer status, without actually shutting down. What we have in mind here is, for example, a bedand-breakfast that has a hired maid prior to the storm, but whose proprietor or an unpaid family member cleans the room in the aftermath of the storm; or a small store or restaurant that lets its two or three employees go but continues to serve customers. If such transitions to non-employer status become more common due to storm damaged, our estimates of exit may overstate the true exits following storm damage; moreover, these transitions to nonemployment may also vary by gender. We address this concern by supplementing the LBD data in this analysis with observations from the ILBD, switching a business's status from exiter to continuer (non-exiter) if it continues operating, and earning positive revenues, as a non-employer. Estimates of Equation (3) using this augmented dataset are not qualitatively different. $^{21}$ In other words, the pattern of coefficients on the differential effect of storm

\footnotetext{
${ }^{21}$ The main differences is a shifting of storm-related exits previously assigned to $2004-06$ to the later time period, which reduces the coefficient on extensive/catastrophic damage in the short run (to about
} 
damage on male- and female-owned businesses is not driven by transitions to non-employer status.

Given the small number of observations used in estimation and the lack of a complete set of control variables, we view these results as suggestive rather than definitive. However, they confirm and add nuance to our main results, showing that relative to the male control group female owned businesses are more vulnerable when hit harder by a cost shock such as the one represented by Katrina.

\subsection{Discussion}

Our results show that young, small, and female-owned businesses have higher exit rates following a cost shock than their similarly affected older, larger, and male-owned counterparts, and that this differential response to the shock cannot be fully explained by productivity differentials. Understanding these patterns requires that we consider the presence of binding constraints that differentially affect the cost of rebuilding. In our setting, these constraints serve as a selection mechanism for young, small, and female-owned businesses and raise the question of whether their excess exit is efficient or wasteful.

There are several theoretical models that introduce frictions in financial and labor markets consistent with our results. In Clementi and Hopenhayn (2006), small and young firms face borrowing constraints due to asymmetric information regarding their profitability. Obtaining the optimal amount of financing hinges on the firm's expected discounted value of future cash flows, which is increasing in the age and size of the business. Insofar as this is higher for male- than female-owned businesses, this model could also explain observed gender survival patterns. Caballero and Hammour (2005) develop a model in which an

0.11 , significant at the $1 \%$ level) and increases it in the medium run (to about 0.26 , significant at the $1 \%$ level). The coefficient on the interaction of extensive/catastrophic damage and female ownership is virtually unchanged in the short run (and remains significant at the 1\% level), but it increases in absolute value, from -0.14 to -0.26 , in the medium run (remaining significant at the $1 \%$ level). The full results from these regressions are available upon request. 
increasing marginal cost of opening a business can lead to excess scrapping of otherwiseprofitable projects in response to a negative shock. ${ }^{22}$ If small, young, and female-owned businesses face higher costs of rebuilding (for example, because of higher labor selection and training costs, higher material or installation costs, lack of internal funds, managerial time constraints, or limited expertise), we will observe them exit at higher rates. Both models imply higher exit rates for constrained businesses that might otherwise be profitable. ${ }^{23}$ As businesses age and grow larger this selection mechanism diminishes in importance.

In addition to these explanations, young and small businesses may have different attitudes towards risk than older and larger businesses, perhaps because their sources of funding are different. Our results are consistent with the possibility that some businesses exited voluntarily because returning to operation would have been profit maximizing in expectation but risky (e.g., due to uncertainty about the local economy's rebounding). Smith (2012, p. 229) reports that many small-business owners declined government loans at low and even zero interest, "pulled down by worry about when and how they would be able to pay it all back." Small-business owners' risk-averse behavior may be further explained by the need to provide personal property as collateral for commercial loans. Gender differences in exit patterns are consistent with this explanations, given evidence that women are more risk averse than men (see Croson and Gneezy, 2009).

The decision to rebuild and reopen may have included considerations other than the success of a particular business establishment. Particularly for large, multi-state operations, investments may not have immediate and local returns. There is some anecdotal evidence that larger firms used the Katrina rebuilding effort in their public-relations efforts. For example, a Wal-Mart press release announcing the reopening of its Waveland, Mississippi, store in August 2006 read in part: "After its building was damaged by Katrina ... the

\footnotetext{
${ }^{22}$ Caballero and Hammour model responses to cyclical demand shocks but their insights extend to shocks more generally.

${ }^{23}$ The reverse is also possible: unconstrained businesses that should otherwise exit might remain in operation, as in Caballero, Hoshi, and Kashyap (2008).
} 
Waveland Wal-Mart quickly erected a 16,000-square foot tent on its lot to ensure people could buy food and basic items. As power across the county remained down for weeks, it was crucial for residents of this hurricane- ravaged community to replace lost items, buy food, cleaning supplies, refill prescriptions, process film and get cellular telephones connected in the storm's aftermath" (Newswires, 2006). Other large enterprises also garnered considerable media attention with their quick reopening. The return of the casino hotel "Beau Rivage" in October 2006, for example, generated considerable media attention (see, e.g., Ball, 2006).

\section{Concluding Remarks}

Our analysis uses Hurricane Katrina as a natural experiment to examine the impact of an external cost shock on business activity. We focus on the differential effect of the shock by firm age, firm size, and owner gender: business characteristics previously associated with access to credit.

We document several facts. First, establishments belonging to young and small firms were disproportionately affected by storm damage. These firms are more vulnerable in the face of catastrophic physical damage, and they exit in large numbers following the initial shock. Second, survivors from this initial shock are more resilient than establishments that never experienced the effects of the storm. We attribute this to a dual selection effect whereby resource-constrained and less-productive businesses exit early. Third, young and small businesses that survive are particularly resilient in this regard and exit at relatively low rates compared to mature and larger business. Medium- and long-run exit rates among small and young businesses that survived the immediate aftermath of the storm are so low that larger and older damaged businesses exit at higher rates than these surviving small and young businesses. These estimates control for other observable establishment and firm characteristics, including establishment productivity.

We also find selection on productivity, both across the board and to a greater degree 
among damaged businesses. The latter finding points to some "cleansing," in the sense that the cost shock selects out less-productive establishments.

We supplement these results with estimates of the effect of storm damage on sole proprietors, a population of businesses that are uniformly small, so any size-specific demand shock would have hit these businesses uniformly. Within this set of businesses, we find that having experienced extensive or catastrophic storm damage had twice the effect on female-owned businesses as on male-owned businesses in the short run. In the long run, female-owned businesses were more resilient than their male-owned counterparts.

Our results suggest that binding constraints other than those presented by a firm's profitability serve as a selection mechanism for young, small and female-owned businesses following a cost shock. We are agnostic as to the particular mechanism at work. Whether due to difficulties accessing credit from financial institutions, risk aversion on the part of business owners with limited personal resources, or higher marginal costs of rebuilding, only a small subset of these businesses survive the initial shock. As businesses age and grow, this selection mechanism diminishes in importance. But young and small businesses that face a major cost shock early in their development cannot reach this later phase. 


\section{References}

Ball, M. (2006) "The comeback Coast," New Orleans Time-Picayune, October 9.

Basker, E. (2006) "When Good Instruments Go Bad: A Reply to Neumark, Zhang, and Ciccarella," unpublished paper, University of Missouri.

(2012) "Raising the Barcode Scanner: Technology and Productivity in the Retail Sector," American Economic Journal: Applied Economics, 4(3), 1-29.

Basker, E., and M. Noel (2009) "The Evolving Food Chain: Competitive Effects of WalMart's Entry into the Supermarket Industry," Journal of Economics and Management Strategy, 18(4), 977-1009.

Belasen, A. R., and S. W. Polachek (2009) "How Disasters Affect Local Labor Markets: The Effects of Hurricanes in Florida," Journal of Human Resources, 44(1), 251-276.

Betancourt, R. R. (2005) The Economics of Retailing and Distribution. Edward Elgar, Cheltenham, UK, and Northampton, MA, USA.

Blanchflower, D. G., P. B. Levine, and D. J. Zimmerman (2003) "Discrimination in the Small Business Credit Market," Review of Economics and Statistics, 85(4), 930-943.

Brown, D., and J. Earle (2013) "Do SBA Loans Create Jobs?," IZA Discussion Paper 7544.

Caballero, R. J., and M. L. Hammour (1994) "The Cleansing Effect of Recessions," American Economic Review, 84(5), 1350-1368.

- (1996) "On the Timing and Efficiency of Creative Destruction," Quarterly Journal of Economics, 111(3), 805-852.

(2005) "The Cost of Recessions Revisited: A Reverse-Liquidationist View," American Economic Review, 72(2), 313-341.

Caballero, R. J., T. Hoshi, and A. K. Kashyap (2008) "Zombie Lending and Depressed Restructuring in Japan," American Economic Review, 98(5), 1943-1977.

Calomiris, C., and G. Hubbard (1990) "Firm Heterogeneity, Internal Finance and Credit Rationing," Economic Journal, 100(399), 90-104.

Chatterji, A. K., and R. C. Seamans (2012) "Entrepreneurial Finance, Credit Cards and Race," Journal of Financial Economics, 106(1), 182-195.

Clementi, G. L., and H. A. Hopenhayn (2006) "A Theory of Financing Constraints and Firm Dynamics," The Quarterly Journal of Economics, 121(1), 229-265.

Cole, R. A., and H. Mehran (2001) "Gender and the Availability of Credit to Privately Held Firms: Evidence from the Surveys of Small Business Finances," unpublished paper, DePaul University and Federal Reserve Bank of New York. 
Coleman, S., and A. Robb (2009) "A Comparison of New Firm Financing by Gender: Evidence from the Kauffman Firm Survey Data," Small Business Economics, 33, 397-411.

Croson, R., and U. Gneezy (2009) "Gender Differences in Preferences," Journal of Economic Literature, 47(2), 448-474.

Davis, S., J. Haltiwanger, and S. Schuh (1996) Job Creation and Destruction. MIT Press, Cambridge, MA.

Davis, S. J., J. Haltiwanger, R. S. Jarmin, C. Krizan, J. Miranda, A. Nucci, and K. Sandusky (2009) "Measuring the Dynamics of Young and Small Businesses: Integrating the Employer and Nonemployer Universes," in Producer Dynamics: New Evidence from Micro Data, ed. by J. B. Jensen, T. Dunne, and M. J. Roberts. University of Chicago Press.

Deryugina, T., L. Kawano, and S. Levitt (2013) "The Economic Impact of Hurricane Katrina on its Victims: Evidence from Individual Tax Returns," unpublished paper.

Doms, M., T. Dunne, and M. J. Roberts (1995) "The role of technology use in the survival and growth of manufacturing plants," International Journal of Industrial Organization, $13(4), 523-542$.

Doms, M. E., R. S. Jarmin, and S. D. Klimek (2004) "Information Technology Investment and Firm Performance in U.S. Retail Trade," Economics of Innovation and New Technology, 13(7), 595-613.

Dunne, T., M. J. Roberts, and L. Samuelson (1988) "Patterns of Firm Entry and Exit in U.S. Manufacturing Industries," RAND Journal of Economics, 19(4), 495-515.

Ewing, B. T., and J. B. Kruse (2005) "Hurricanes and Unemployment," unpublished paper, East Carolina University Center for Natural Hazards Research.

Fazzari, S. M., R. G. Hubbard, and B. C. Petersen (1988) "Financing Constraints and Corporate Investment," Brookings Papers on Economic Activity, 1988(1), 141-206.

Federal Emergency Management Agency (2006) "Summary Report on Building Performance: Hurricane Katrina 2005," Discussion Paper 548, FEMA.

Fort, T., J. Haltiwanger, R. Jarmin, and J. Miranda (2013) "How Firms Respond to Business Cycles: The Role of Firm Age and Firm Size," IMF Economic Review, 61(3), 520-559.

Foster, L., J. Haltiwanger, and C. J. Krizan (2002) "The Link between Aggregate and Micro Productivity Growth: Evidence from Retail Trade," National Bureau of Economic Research Working Paper 9120.

General Accounting Office (2010) "Hurricanes Katrina and Rita," Discussion Paper GAO10-723, GAO.

Gertler, M., and S. Gilchrest (1994) "Monetary Policy, Business Cycles, and the Behavior of Small Manufacturing Firms," Quarterly Journal of Economics, 109(2), 309-340. 
Groen, J., M. Kutzbach, and A. Polivka (2013) "Storms and Jobs: The Effect of Hurricanes on Individuals' Employment and Earnings Over the Long Term," unpublished paper.

Haltiwanger, J., R. Jarmin, and J. Miranda (2013) "Who Creates Jobs? Small vs. Large vs. Young," Review of Economics and Statistics, 95(2), 347-361.

Haskel, J., and R. Sadun (2009) "Entry, Exit and Labour Productivity in UK Retailing: Evidence from Micro Data," in Producer Dynamics: New Evidence from Micro Data, ed. by J. B. Jensen, T. Dunne, and M. J. Roberts. University of Chicago Press.

Hosono, K., D. Miyakawa, T. Uchino, M. Hazama, A. Ono, H. Uchida, and I. Uesugi (2012) "Natural Disasters, Bank Lending, and Firm Investment," Research Institute of Economy, Trade, and Industry (RIETI) Discussion Paper 12-E-062.

Jarmin, R. S. (1999) "Government Technical Assistance Programs and Plant Survival: The Role of Plant Ownership Type," unpublished paper, U.S. Census Bureau.

Jarmin, R. S., and J. Miranda (2002) "The Longitudinal Business Database," unpublished paper, U.S. Census Bureau.

(2009) "The Impact of Hurricanes Katrina, Rita and Wilma on Business Establishments," Jounral of Business Valuation and Economic Loss Analysis, 4(2), article 7.

Kast, S. (2005) "Disaster Bridge Loan Deadline Extended to Jan. 31 for Southernmost Counties," US Fed News.

Knabb, R. D., J. R. Rhome, and D. P. Brown (2005) "Tropical Cyclone Report: Hurricane Katrina," Discussion Paper AL122005, National Hurricane Center.

Leiter, A. M., H. Oberhofer, and P. A. Raschky (2009) "Creative Disasters? Flooding Effects on Capital, Labour and Productivity within European Firms," Environmental and Resource Economics, 43(3), 333-350.

Mishkin, F. (2008) "Small Business Lending," Testimony before the Committee on Small Business and Entrepreneurship, U.S. Senate.

Newswires, P. (2006) "Wal-Mart Supercenter Returns to Waveland With Gulf Coast Community Celebration," PR Newswires, August 3.

Robb, A. M., R. W. Fairlie, and D. T. Robinson (2009) "Financial Capital Injections among New Black and White Business Ventures: Evidence from the Kauffman Firm Survey," unpublished paper, University of California, Santa Cruz and Duke University.

Sayre, E. A., and D. Butler (2011) "The Geography of Recovery: An Analysis of the Mississippi Gulf Coast after Hurricane Katrina," unpublished paper, University of Southern Mississippi.

Sharpe, S. (1994) "Financial Market Imperfections, Firm Leverage, and the Cyclicality of Employment," American Economic Review, 84(4), 1060-74. 
Siodla, J. (2013) "Making the Move: The Impact of the 1906 San Francisco Disaster on Firm Relocations," unpublished paper, Colby College.

Small Business Administration (2008) "Annual Performance Report," Discussion Paper GAO-041-076, SBA.

Smith, J. P. (2012) Hurricane Katrina: The Mississippi Story. University Press of Mississippi, Jackson, MS.

Strobl, E. (2011) "The Economic Growth Impact of Hurricanes: Evidence from U.S. Coastal Counties," Review of Economcis and Statistics, 93(2), 575-589. 


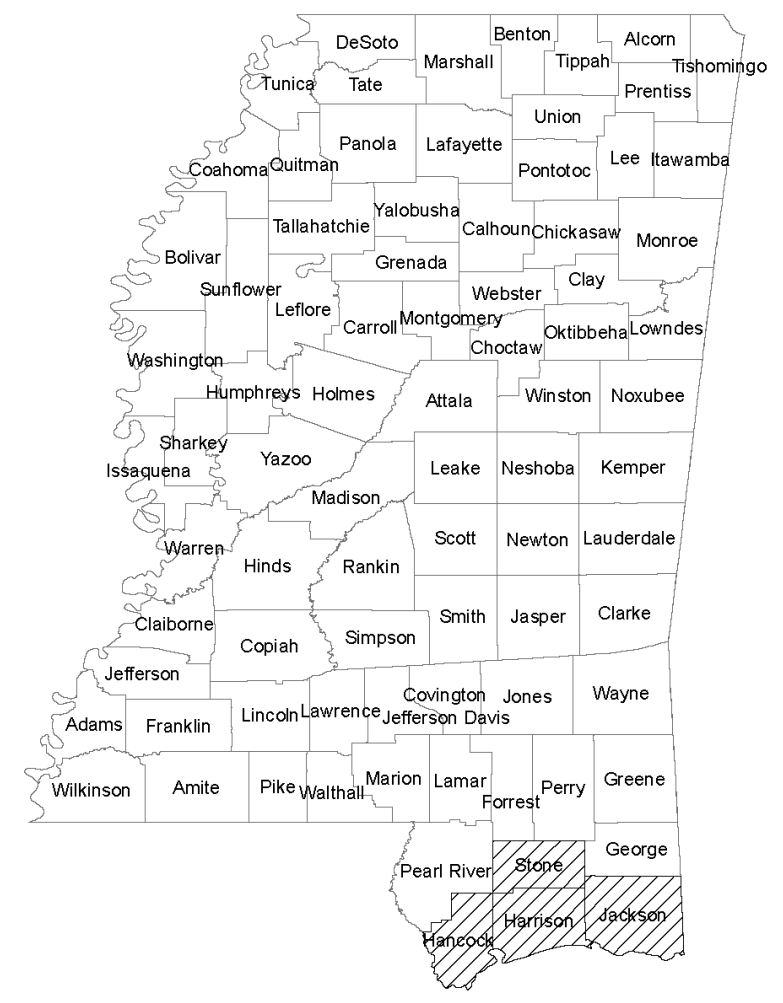

Figure 1. Mississippi (Shaded Counties Most Affected by Katrina)

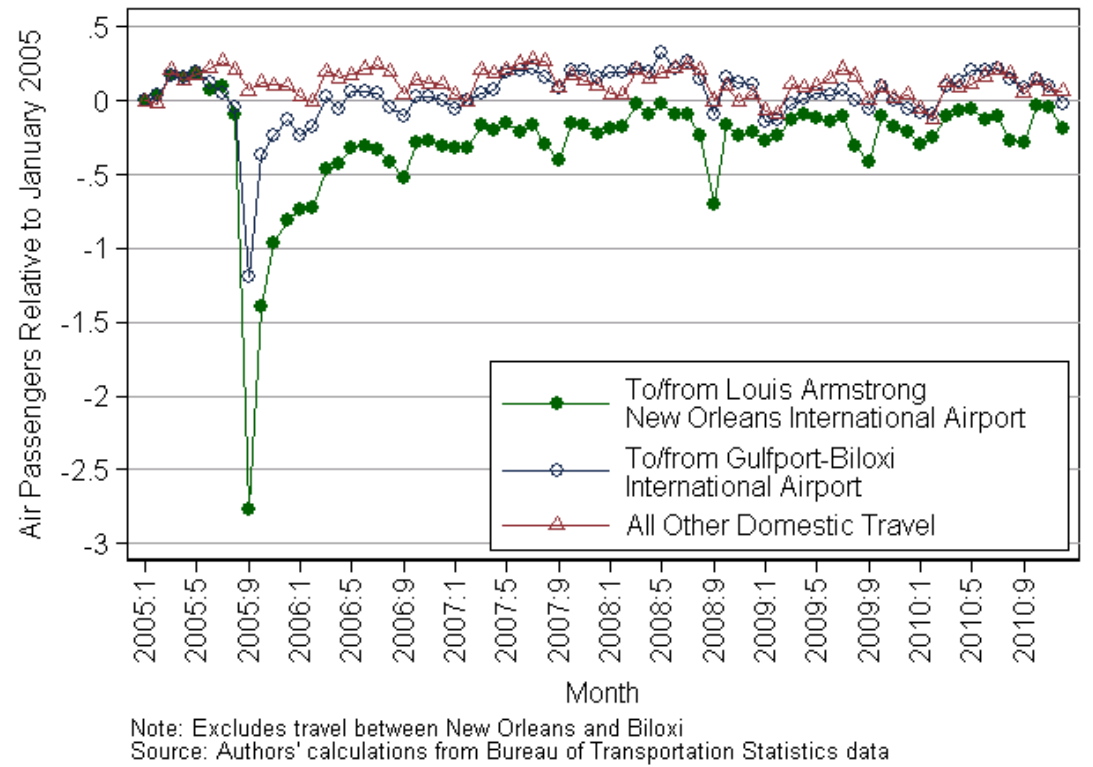

Figure 2. Air Passenger Travel to and from New Orleans and Biloxi, 2005-2010 


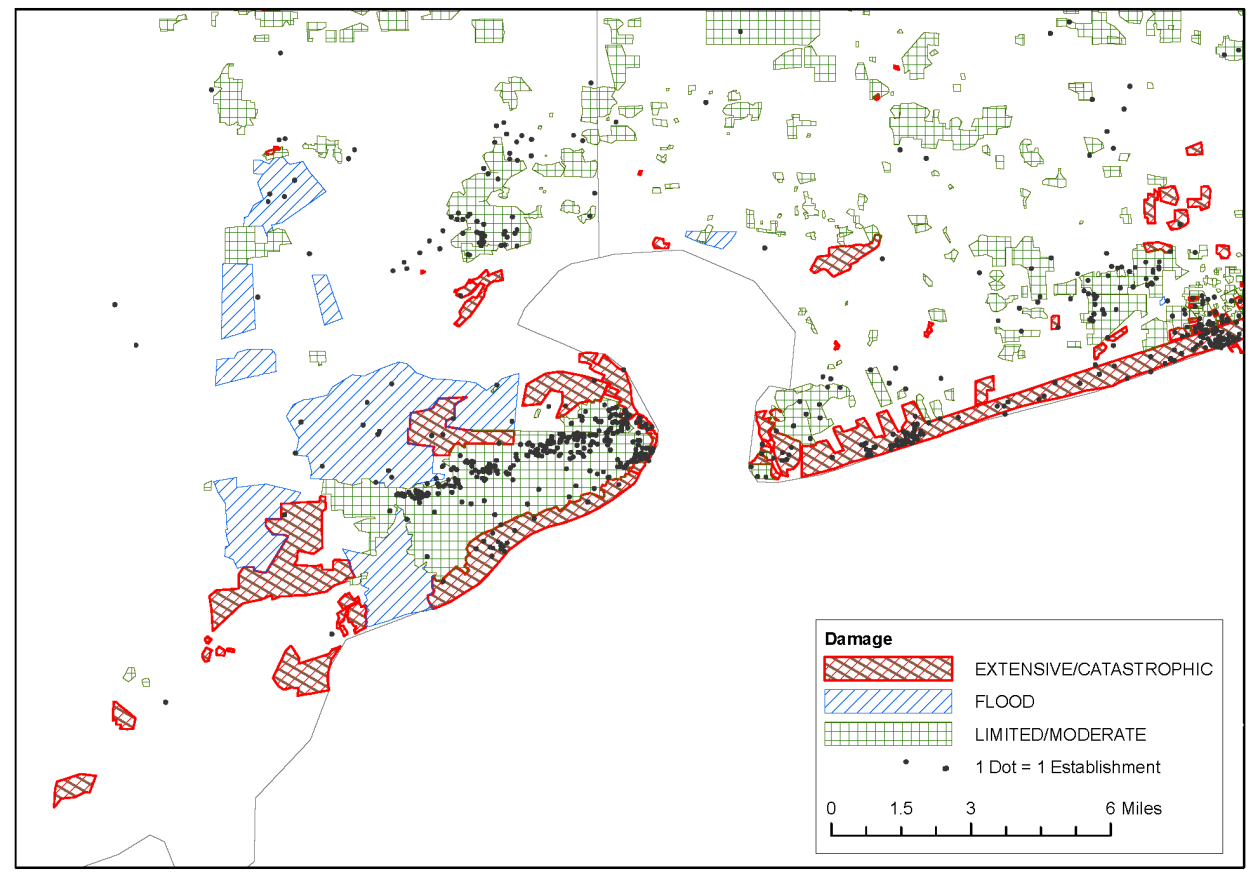

Figure 3. Damage Area Closeup: Harrison and Hancock Counties, MS

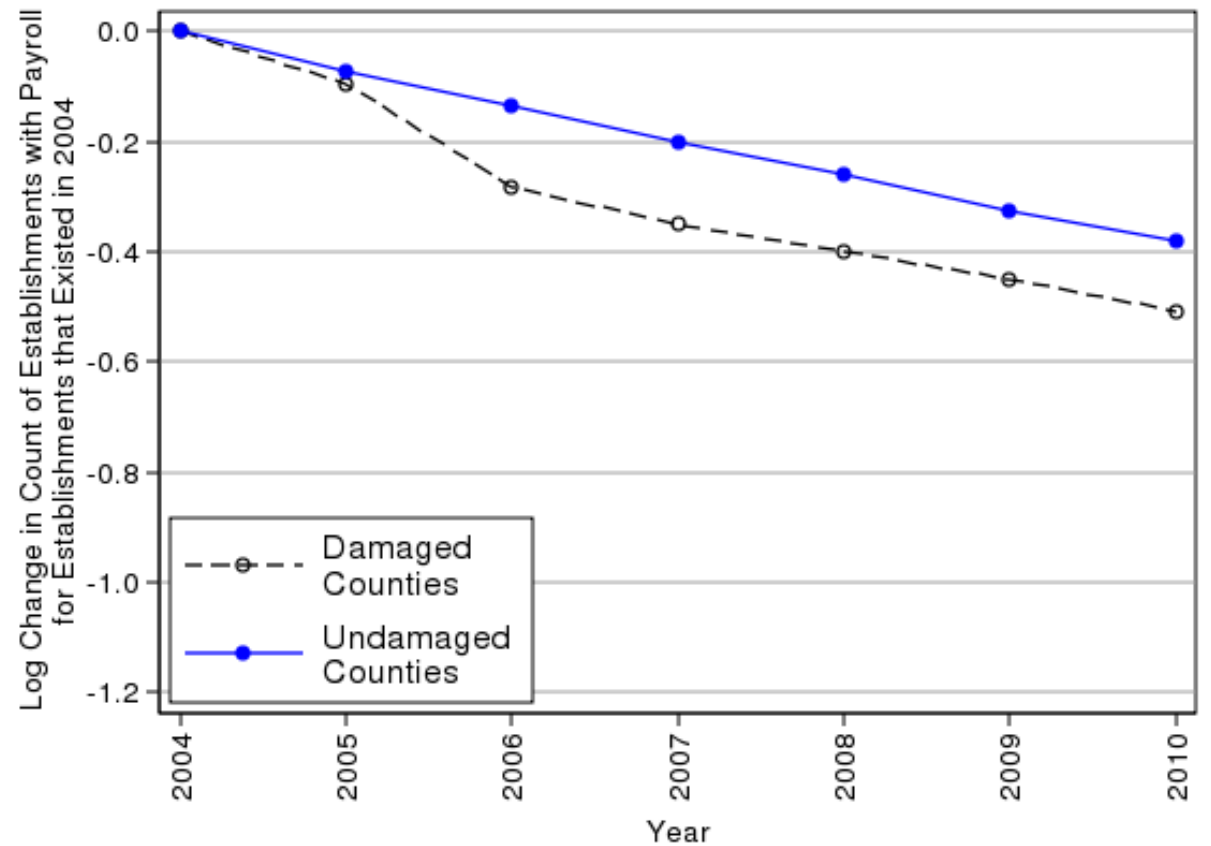

Figure 4. Log Change, since 2004, in Stores, Restaurants, and Hotels that Existed in 2002 in Mississippi 


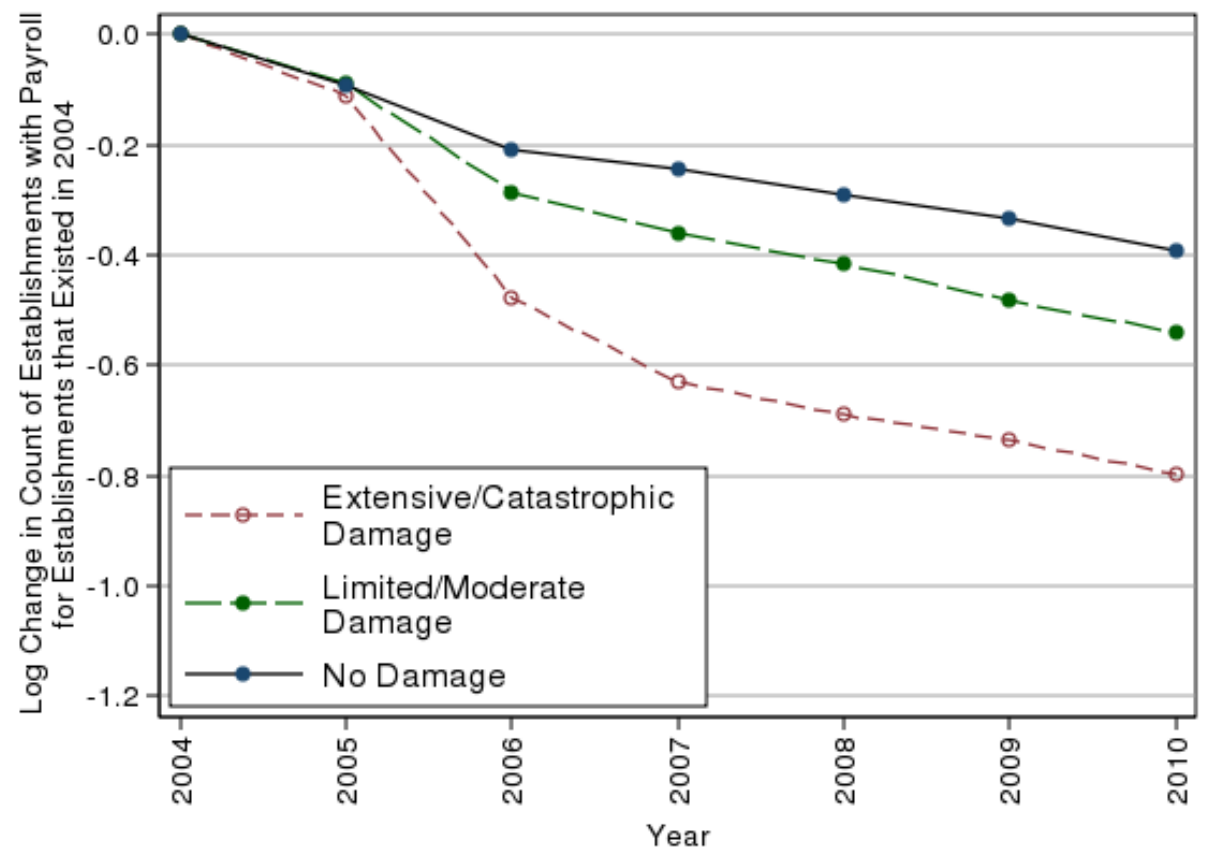

Figure 5. Log Change, since 2004, in Stores, Restaurants, and Hotels that Existed in 2002 in Damaged Counties 
Table 1. Population of Selected Mississippi Counties 2000-2010

\begin{tabular}{lrrr}
\hline & 2000 & 2010 & Log \\
County & Population & Population & Change \\
\hline \hline Hancock & 42,967 & 43,929 & $+2.2 \%$ \\
Harrison & 189,601 & 187,105 & $-1.3 \%$ \\
Jackson & 131,420 & 139,668 & $+6.1 \%$ \\
Stone & 13,622 & 17,786 & $+26.7 \%$ \\
\hline Rest of State & $2,467,048$ & $2,578,809$ & $+4.4 \%$ \\
\hline
\end{tabular}

Source: Authors' Calculations from Population

Census, 2000 and 2010

Table 2. County Summary Statistics, 2004

\begin{tabular}{llrrcc}
\hline State & County & Estabs & $\begin{array}{c}\text { Geo- } \\
\text { Coded }\end{array}$ & $\begin{array}{c}\text { Extensive or } \\
\text { Catastrophic }\end{array}$ & $\begin{array}{c}\text { Limited or } \\
\text { Moderate }\end{array}$ \\
\hline \hline MS & Hancock & 170 & 150 & $10.7 \%$ & $68.0 \%$ \\
MS & Harrison & 975 & 852 & $35.3 \%$ & $16.9 \%$ \\
MS & Jackson & 501 & 435 & $6.9 \%$ & $18.2 \%$ \\
MS & Stone & 56 & 46 & & \\
MS & Rest of State & 10,629 & 8,513 & & $0.3 \%$ \\
\hline Total & & 12,331 & 9,996 & $3.5 \%$ & $3.5 \%$ \\
\hline
\end{tabular}

Establishment counts represent the retail, restaurant, and hotel sectors.

Damage counts are percentages of geocoded establishments.

Blank cells indicate a cell was suppressed to comply with confidentiality standards.

Table 3. Establishment Summary Statistics: All Establishments, 2004

\begin{tabular}{lcrrrr}
\hline & & \multicolumn{1}{c}{$\begin{array}{c}\text { Non- } \\
\text { Gariable }\end{array}$} & Estabs & \multicolumn{1}{c}{ All } & \multicolumn{1}{c}{ Geocoded } \\
coded & T-test $^{\mathrm{a}}$ \\
\hline \hline Single-unit firms (\%) & 12,331 & 59.4 & 55.5 & 60.3 & 0.000 \\
Establishments in firm & 12,331 & 460.3 & 476.5 & 456.5 & 0.513 \\
Establishment employment & 12,331 & 17.6 & 16.2 & 17.9 & 0.271 \\
\hline Establishment age & 12,331 & 12.8 & 12.6 & 12.9 & 0.930 \\
Firm age & 12,331 & 18.1 & 18.8 & 17.9 & 0.000 \\
Productivity & 12,331 & 4.5 & 4.5 & 4.5 & 0.425 \\
\hline b & & & &
\end{tabular}

Establishment counts represent the retail, restaurant, and hotel sectors.

${ }^{a}$ p-value from t-test for equality of the means

${ }^{b} \log$ ratio of revenue to employment in 2002 
Table 4. Establishment Summary Statistics: Geocoded Establishments, 2004

\begin{tabular}{llrrrr}
\hline Variable & Estabs & \multicolumn{1}{c}{ All } & Undamaged & Damaged & T-test $^{\mathrm{a}}$ \\
\hline \hline Single-unit firms (\%) & 9,996 & 60.3 & 60.2 & 60.4 & 0.953 \\
Establishments in firm & 9,996 & 456.5 & 451.2 & 529.5 & 0.136 \\
Firm age & 9,996 & 17.9 & 17.9 & 17.6 & 0.449 \\
\hline Establishment employment & 9,996 & 17.9 & 17.9 & 18.6 & 0.785 \\
Establishment age & 9,996 & 12.9 & 12.9 & 12.8 & 0.660 \\
Productivity & 9,996 & 4.5 & 4.5 & 4.4 & 0.000 \\
\hline
\end{tabular}

Establishment counts represent the retail, restaurant, and hotel sectors.

${ }^{a}$ p-value from t-test for equality of means

${ }^{\mathrm{b}} \log$ ratio of revenue to employment in 2002

Table 5. Establishment Summary Statistics: Sole Proprietorships, 2004

\begin{tabular}{llrrrr}
\hline Variable & Estabs & All & Undamaged & Damaged & T-test $^{\mathrm{a}}$ \\
\hline \hline Female owner & 1,339 & 0.3 & 0.3 & 0.3 & 0.205 \\
Firm age & 1,339 & 12.9 & 12.9 & 12.6 & 0.728 \\
\hline Establishment employment & 1,339 & 4.6 & 4.6 & 4.5 & 0.935 \\
Establishment age & 1,339 & 12.4 & 12.5 & 11.7 & 0.401 \\
Productivity & 1,339 & 4.5 & 4.5 & 4.2 & 0.270 \\
\hline
\end{tabular}

Establishment counts represent the retail, restaurant, and hotel sectors.

${ }^{a}$ p-value from t-test for equality of means

${ }^{b} \log$ ratio of revenue to employment in 2002 
Table 6. Difference-in-Difference Exit Regressions: Firm Age and Damage

\begin{tabular}{|c|c|c|c|c|}
\hline & $2002-04$ & $2004-06$ & $2006-08$ & $2008-10$ \\
\hline \multirow{2}{*}{$\begin{array}{l}\text { Extensive/Catastrophic } \\
\text { Damage }\end{array}$} & 0.0415 & $0.5415^{* * *}$ & 0.0118 & $\overline{-0.2482^{* * *}}$ \\
\hline & $(0.0372)$ & $(0.0537)$ & $(0.1455)$ & $(0.0350)$ \\
\hline \multirow{2}{*}{$\begin{array}{l}\text { Limited/Moderate } \\
\text { Damage }\end{array}$} & 0.0692 & 0.1675 & 0.0329 & -0.0337 \\
\hline & $(0.0571)$ & $(0.1848)$ & $(0.1426)$ & $(0.0774)$ \\
\hline \multirow[t]{2}{*}{$\ln$ (Firm Age) } & $-0.0353^{* * *}$ & $-0.0327^{* * *}$ & $-0.0324^{* * *}$ & $-0.0511^{* * *}$ \\
\hline & $(0.0056)$ & $(0.0055)$ & $(0.0076)$ & $(0.0101)$ \\
\hline \multirow[t]{2}{*}{$\mathbb{I}(\text { Firm Age }=0)^{\mathrm{a}}$} & $0.0672^{* * *}$ & & & \\
\hline & $(0.0253)$ & & & \\
\hline \multirow{2}{*}{$\begin{array}{l}\text { Extensive/Catastrophic } \\
\quad \times \ln (\text { Age })\end{array}$} & -0.0065 & $-0.0651^{* * *}$ & $0.1191^{* * *}$ & $0.0839^{* * *}$ \\
\hline & $(0.0071)$ & $(0.0098)$ & $(0.0117)$ & $(0.0255)$ \\
\hline \multirow{2}{*}{$\begin{array}{l}\text { Limited/Moderate } \\
\quad \times \ln (\text { Age })\end{array}$} & 0.0024 & -0.0095 & 0.0205 & -0.0350 \\
\hline & $(0.0188)$ & $(0.0582)$ & $(0.0334)$ & $(0.0309)$ \\
\hline \multirow{2}{*}{$\begin{array}{l}\text { Extensive/Catastrophic } \\
\quad \times \mathbb{I}(\text { Age }=0)\end{array}$} & -0.0729 & & & \\
\hline & $(0.0726)$ & & & \\
\hline \multirow{2}{*}{$\begin{array}{l}\text { Limited/Moderate } \\
\quad \times \mathbb{I}(\text { Age }=0)\end{array}$} & -0.0932 & & & \\
\hline & $(0.0951)$ & & & \\
\hline \multirow[t]{2}{*}{$\ln ($ Firm Size $)$} & $-0.0086^{* * *}$ & $-0.0084^{* * *}$ & $-0.0081^{* * *}$ & $-0.0064^{* * *}$ \\
\hline & $(0.0013)$ & $(0.0013)$ & $(0.0019)$ & $(0.0017)$ \\
\hline \multirow[t]{2}{*}{$\ln$ (Productivity) } & $-0.0844^{* * *}$ & $-0.0453^{* * *}$ & $-0.0241^{* * *}$ & $-0.0151^{*}$ \\
\hline & $(0.0067)$ & $(0.0064)$ & $(0.0072)$ & $(0.0077)$ \\
\hline \multirow{2}{*}{$\begin{array}{l}\text { Extensive/Catastrophic } \\
\times \ln (\text { Prod })\end{array}$} & -0.0092 & $-0.0441^{* * *}$ & $-0.0576^{* * *}$ & -0.0003 \\
\hline & $(0.0062)$ & $(0.0058)$ & $(0.0178)$ & $(0.0116)$ \\
\hline \multirow{2}{*}{$\begin{array}{l}\text { Limited/Moderate } \\
\quad \times \ln (\text { Prod })\end{array}$} & $-0.0149^{*}$ & $-0.0279^{* *}$ & -0.0148 & 0.0326 \\
\hline & $(0.0088)$ & $(0.0117)$ & $(0.0263)$ & $(0.0211)$ \\
\hline County FE & $\checkmark$ & $\checkmark$ & $\checkmark$ & $\checkmark$ \\
\hline NAICS FE (6 digit) & $\checkmark$ & $\checkmark$ & $\checkmark$ & $\checkmark$ \\
\hline Observations & 11,252 & 9,996 & 8,552 & 7,546 \\
\hline Percent predicted outside $[0,1]$ & $10 \%$ & $3 \%$ & $2 \%$ & $1 \%$ \\
\hline
\end{tabular}

Robust standard errors in parentheses, clustered by county.

* significant at $10 \%$; $* *$ significant at $5 \% ; * * *$ significant at $1 \%$

a Age of zero occurs only in 2002 sample; later samples are continuers from 2002 
Table 7. Difference-in-Difference Exit Regressions: Firm Size and Damage

\begin{tabular}{|c|c|c|c|c|}
\hline & $2002-04$ & $2004-06$ & $2006-08$ & $2008-10$ \\
\hline \multirow{2}{*}{$\begin{array}{l}\text { Extensive/Catastrophic } \\
\text { Damage }\end{array}$} & 0.0304 & $0.3967 * * *$ & $0.3327^{* *}$ & -0.0319 \\
\hline & $(0.0349)$ & $(0.0448)$ & $(0.1338)$ & $(0.0508)$ \\
\hline \multirow{2}{*}{$\begin{array}{l}\text { Limited/Moderate } \\
\text { Damage }\end{array}$} & 0.0677 & $0.1538^{*}$ & 0.0737 & -0.1248 \\
\hline & $(0.0491)$ & $(0.0916)$ & $(0.1132)$ & $(0.0769)$ \\
\hline \multirow[t]{2}{*}{$\ln ($ Firm Size $)$} & $-0.0088^{* * *}$ & $-0.0072^{* * *}$ & $-0.0083^{* * *}$ & $-0.0065^{* * *}$ \\
\hline & $(0.0012)$ & $(0.0014)$ & $(0.0019)$ & $(0.0018)$ \\
\hline \multirow{2}{*}{$\begin{array}{l}\text { Extensive/Catastrophic } \\
\quad \times \ln (\text { Size })\end{array}$} & 0.0026 & $-0.0217^{* * *}$ & $0.0058^{* * *}$ & $0.0069^{* * *}$ \\
\hline & $(0.0019)$ & $(0.0018)$ & $(0.0020)$ & $(0.0024)$ \\
\hline \multirow{2}{*}{$\begin{array}{l}\text { Limited/Moderate } \\
\quad \times \ln (\text { Size })\end{array}$} & 0.0026 & -0.0087 & 0.0048 & -0.0026 \\
\hline & $(0.0037)$ & $(0.0087)$ & $(0.0092)$ & $(0.0055)$ \\
\hline \multirow[t]{2}{*}{$\ln ($ Firm Age $)$} & $-0.0354^{* * *}$ & $-0.0354^{* * *}$ & $-0.0296^{* * *}$ & $-0.0505^{* * *}$ \\
\hline & $(0.0053)$ & $(0.0050)$ & $(0.0087)$ & $(0.0100)$ \\
\hline \multirow[t]{2}{*}{$\mathbb{I}(\text { Firm Age }=0)^{\mathrm{a}}$} & $0.0617^{* *}$ & & & \\
\hline & $(0.0247)$ & & & \\
\hline \multirow[t]{2}{*}{$\ln$ (Productivity) } & $-0.0844^{* * *}$ & $-0.0452^{* * *}$ & $-0.0243^{* * *}$ & $-0.0152^{*}$ \\
\hline & $(0.0066)$ & $(0.0064)$ & $(0.0072)$ & $(0.0077)$ \\
\hline \multirow{2}{*}{$\begin{array}{l}\text { Extensive/Catastrophic } \\
\quad \times \ln (\text { Prod })\end{array}$} & $-0.0119^{*}$ & $-0.0388^{* * *}$ & $-0.0547^{* *}$ & 0.0035 \\
\hline & $(0.0065)$ & $(0.0057)$ & $(0.0210)$ & $(0.0092)$ \\
\hline \multirow{2}{*}{$\begin{array}{l}\text { Limited/Moderate } \\
\quad \times \ln (\text { Prod })\end{array}$} & $-0.0149^{* *}$ & $-0.0270^{*}$ & -0.0130 & 0.0311 \\
\hline & $(0.0074)$ & $(0.0143)$ & $(0.0261)$ & $(0.0196)$ \\
\hline \multirow{2}{*}{$\begin{array}{l}\text { County FE } \\
\text { NAICS FE (6 digit) }\end{array}$} & $\checkmark$ & $\checkmark$ & $\checkmark$ & $\checkmark$ \\
\hline & $\checkmark$ & $\checkmark$ & $\checkmark$ & $\checkmark$ \\
\hline \multirow{2}{*}{$\begin{array}{l}\text { Observations } \\
\text { Percent predicted outside }[0,1]\end{array}$} & 12,252 & 9,996 & 8,552 & 7,546 \\
\hline & $9 \%$ & $2 \%$ & $2 \%$ & $1 \%$ \\
\hline
\end{tabular}

Robust standard errors in parentheses, clustered by county.

* significant at $10 \% ; * *$ significant at $5 \%$; $* * *$ significant at $1 \%$

a Age of zero occurs only in 2002 sample; later samples are continuers from 2002 
Table 8. Difference-in-Difference Exit Regressions: Owner Gender and Damage

\begin{tabular}{|c|c|c|c|c|}
\hline & $2002-04$ & $2004-06$ & 2006-08 & $2008-10$ \\
\hline \multirow{2}{*}{$\begin{array}{l}\text { Extensive/Catastrophic } \\
\text { Damage }\end{array}$} & -0.0307 & $0.1816^{* * *}$ & $0.1986^{* * *}$ & $0.1263^{* * *}$ \\
\hline & $(0.0264)$ & $(0.0624)$ & $(0.0256)$ & $(0.0305)$ \\
\hline \multirow{2}{*}{$\begin{array}{l}\text { Limited/Moderate } \\
\text { Damage }\end{array}$} & -0.0191 & 0.1130 & $-0.1479^{* * *}$ & $0.1660^{* *}$ \\
\hline & $(0.0412)$ & $(0.1088)$ & $(0.0423)$ & $(0.0775)$ \\
\hline \multirow{2}{*}{$\begin{array}{l}\text { Female-Owned } \\
\text { Business }\end{array}$} & -0.0157 & 0.0110 & 0.0382 & 0.0326 \\
\hline & $(0.0239)$ & $(0.0298)$ & $(0.0286)$ & $(0.0365)$ \\
\hline \multirow{2}{*}{$\begin{array}{l}\text { Extensive/Catastrophic } \\
\times \text { Female-Owned }\end{array}$} & $0.0857^{* *}$ & $0.2250^{* * *}$ & $-0.1393^{* * *}$ & -0.1587 \\
\hline & $(0.0341)$ & $(0.0387)$ & $(0.0444)$ & $(0.1690)$ \\
\hline \multirow{2}{*}{$\begin{array}{l}\text { Limited/Moderate } \\
\times \text { Female-Owned }\end{array}$} & -0.0729 & -0.0732 & 0.0648 & -0.0783 \\
\hline & $(0.0918)$ & $(0.1093)$ & $(0.0805)$ & $(0.0959)$ \\
\hline \multirow[t]{2}{*}{$\ln$ (Firm Age) } & $-0.0416^{* * *}$ & $-0.0489^{* * *}$ & $-0.0679^{* * *}$ & -0.0340 \\
\hline & $(0.0141)$ & $(0.0172)$ & $(0.0242)$ & $(0.0377)$ \\
\hline \multirow[t]{2}{*}{$\mathbb{I}(\text { Firm Age }=0)^{\mathrm{a}}$} & 0.0383 & & & \\
\hline & $(0.0612)$ & & & \\
\hline \multirow[t]{2}{*}{$\ln$ (Productivity) } & $-0.0937^{* * *}$ & -0.0299 & $-0.0483^{* *}$ & -0.0004 \\
\hline & $(0.0148)$ & $(0.0202)$ & $(0.0201)$ & $(0.0162)$ \\
\hline NAICS FE (4 digit) & $\checkmark$ & $\checkmark$ & $\checkmark$ & $\checkmark$ \\
\hline Observations & 1,672 & 1,339 & 1,017 & 838 \\
\hline Percent predicted outside $[0,1]$ & $2 \%$ & $<1 \%$ & $2 \%$ & $1 \%$ \\
\hline
\end{tabular}

Robust standard errors in parentheses, clustered by county.

* significant at $10 \% ;{ }^{* *}$ significant at $5 \%$; ${ }^{* *}$ significant at $1 \%$

a Age of zero occurs only in 2002 sample; later samples are continuers from 2002 